\title{
Nanogram per Minute
}

National Cancer Institute

\section{Source}

National Cancer Institute. Nanogram per Minute. NCI Thesaurus. Code C85749.

Nanograms per minute. 